\title{
DISCURSOS VISUALES Y MENTALIDAD RELIGIOSA. LA FEMME-AUX-SERPENTS Y EL USO DE IMÁGENES ANTITÉTICAS EN LA ESCULTURA ROMÁNICA
}

Eukene Martínez de Lagos

Universidad del País Vasco

\begin{abstract}
RESUMEN: La iconografía de la femme-aux-serpents como imagen del castigo a la lujuria es uno de los motivos más difundidos en la escultura románica del Occidente europeo. A ello contribuye que algunas de sus primeras representaciones, datadas hacia el 1080, se localicen en templos creadores y difusores de repertorios figurativos. Templos que, además, están vinculados a la influencia de la reforma gregoriana y a la expansión de la orden reformadora de Cluny sin olvidar su destacado emplazamiento en las vías de peregrinación a Santiago de Compostela. Si a ello añadimos la mentalidad monástica en torno a la mujer y la sexualidad y el hecho de que la lujuria sea uno de los pecados primordiales y más combatidos, encontramos el contexto preciso para poder explicar su extraordinario éxito como discurso visual rotundo, contundente e impactante.
\end{abstract}

Palabras clave: Femme-aux-serpents, escultura románica, Camino de Santiago.

\section{VISUAL DISCOURSES AND RELIGIOUS MENTALITY. THE FEMME-AUX-SERPENTS AND THE USE OF ANTITHETIC IMAGES IN ROMANESQUE SCULPTURE}

\begin{abstract}
The iconography of the femme-aux-serpents as image of the punishment to the lust is one of the most widespread topics in the Romanesque sculpture of the European west. Some of the first representations of this iconographical subject, dated about 1080, are located in churches creators and diffusers of figurative romanesque repertories. Moreover, these churches are linked to the influence of the Gregorian reform and to the expansion of the reformer order of Cluny and they have an out-standing emplacement in the pilgrimage routes to Santiago de Compostela. To explain its extraordinary success as visual round, forceful and striking allegation we can add the monastic
\end{abstract}


mentality concerning woman and sexuality and the fact that lust is one of the basic and more attacked sins of Middle ages.

Keywords: Femme-aux-serpents, Romanesque sculpture, The Way of St. James.

En torno a 1080 están datadas las primeras representaciones más significativas de la femme-aux-serpents, significativas no sólo por su cronología, sino por los templos en los que aparecen: Catedral de Santiago de Compostela, Porte des Comtes de Saint-Sernin de Toulouse, Panteón de San Isidoro de León, Catedral de San Pedro de Jaca y San Martín de Frómista'. No puede ser casualidad que los ejemplos más tempranos de este tema iconográfico se sitúen en fábricas románicas de gran trascendencia como centros artísticos difusores de formas y motivos y creo que no hace falta extenderse sobre el hecho de que son centros neurálgicos en el camino de peregrinación a Santiago de Compostela. Todos, nuevamente, son templos cuya construcción, entre otros factores, aparece vinculada a la reforma impulsada por Gregorio VII a partir del año 1074 para unificar la liturgia occidental y todos, una vez más, relacionados en mayor o menor medida con Cluny, orden impulsora de su implantación así como protagonista activa en el desarrollo del Camino².

* Este artículo forma parte de las líneas de investigación que se están abordando en el desarrollo del proyecto de investigación El sentimiento del amor en el Arte de la Baja Edad Media, proyecto subvencionado por el vicerrectorado de Investigación de la UPV/EHU en la modalidad Proyectos de Investigación 14 Tipo B con el número de referencia EHU 14/30 y con Soledad De Silva Verastegui como investigadora principal.

1. Una de las pocas representaciones que parece ser anterior, aunque sin una cronología fija, es un relieve conservado en el Museo de los Agustinos de Toulouse que procede de la pequeña iglesia rural de Oo en el Alto Garona. Datada en el siglo XI y con una factura un tanto tosca y arcaizante es de una plasticidad rotunda, ya que la serpiente surge de la vulva de la mujer para reptar por su cuerpo hasta morderle uno de los senos. F. COLIN-GOGUEL. L'Image de l'Amour charnel au Moyen Age. Ed. Seuil. París, 2008, p. 48. A. WEIR, J. JERMAN. Images of Lust. Sexual carvings on medieval churches. B.T. Batsford Ltd. London, 1986, p. 71. Plate 33.

2. La bibliografía sobre estos cinco templos de referencia es tan amplia que únicamente me he limitado a considerar algunas de las últimas aportaciones, ya que lógicamente el estado de la cuestión que establecen hace referencia a las diferentes hipótesis y a las controversias cronológicas que han rodeado los análisis e investigaciones realizadas a lo largo de los años. En relación a San Isidoro de León y tras los debates suscitados entre quienes defendían la construcción del Panteón Real bajo la promoción de Fernando I y Sancha o de su hija, la Infanta Urraca, las aportaciones más recientes abogan por creerlo obra de esta última y por ello iniciado a partir del año 1072, comienzo de su infantazgo. Acotando un poco más las fechas las obras se realizarían entre el 1080, tras el desafío de su hermano Alfonso VI de situar su enterramiento y el de sus esposas en Sahagún, y 1095-1100, culminación del programa pictórico. Entre los factores barajados para su construcción, además de guarecer los sepulcros, abogar por las almas de los antepasados y proclamar su condición de única y legítima depositaria del pasado dinástico, habría que considerar algunos de los ya reseñados: la reforma papal y el cambio litúrgico, la penetración de los cluniacenses o también el afrancesamiento de la corte, aspectos estos que ya habían empezado a desarrollarse durante el reinado de Fernando I. Ver: F. PRADO-VILAR. "Lacrimae rerum: San Isidoro de 
La difusión de la femme aux serpents en el Occidente europeo coincide con la expansión de esta orden reformadora, orden que jugará un papel decisivo en

León y la memoria del padre". Goya, no 328 (2009), pp. 195-221 y G. BOTO VARELA. "In Legionenssy regum ciminterio. La construcción del cuerpo occidental de San Isidoro de León y el amparo de los invitados a la Cena del Señor". En: Monumentos singulares del románico. Nuevas lecturas sobre formas y usos. Aguilar de Campoo, 2012, pp. 93-135, donde además de sus aportaciones incluyen un completo estado de la cuestión y una actualización de la bibliografía sobre esta singular obra. La representación de Santiago de Compostela está situada en la girola de la catedral y vinculada a la primera fase constructiva de la misma bajo la dirección del obispo Diego Peláez. Su cronología toma como fechas de inicio el año 1075, año en que Alfonso VI viaja a la ciudad para la celebración de un concilio magno en el que precisamente se habla del cambio de rito en la iglesia galaica, o 1077 cuando se establece el documento de concordia realizado entre el abad Fagildo de Antealtares y el obispo Diego Peláez. Esta primera fase de las obras se alargaría hasta el año 1088, momento en que se interrumpen bruscamente por la deposición del obispo citado para reanudarse a partir del año 1095 con la llegada de Diego Gelmírez que termina la construcción del ábside y las capillas. Ver: V.R. NODAR FERNÁNDEZ. "De la Tierra-Madre a la Lujuria: a propósito de un capitel de la girola de la Catedral de Santiago". Semata, vol. 14 (2002), pp. 335347 y sobre todo: Los inicios de la catedral románica de Santiago: el ambicioso programa iconográfico de Diego Peláez. Santiago de Compostela, 2004 y "Obispo, Rey y monasterio, una nueva lectura del programa de la cabecera de la Catedral de Santiago de Compostela". En: Il Medioevo. La Chiesa e il Palazzo. Atti del Convegno internazionale di studi (Parma, 2005). Milán, 2007, pp. 484-490. Con respecto a Toulouse su construcción está vinculada a la edificación de los grandes santuarios de peregrinación iniciados a finales del siglo $\mathrm{XI}$ y sobre todo al contexto reformador impulsado por los Concilios celebrados en 1057 y 1060-61. También a la reforma del Cabildo catedralicio realizada por el obispo Isarn a partir de 1073, quien además va a intentar reemplazar a los canónigos de Saint-Sernin por monjes de Moissac en 1082. Tras numerosas discusiones acerca del comienzo de las obras hoy se sitúa el inicio de la primera fase constructiva en torno a 10731075, con una breve interrupción entre 1082-83, cuando el Papa decide restituir Saint-Sernin a los monjes tolosanos y su final en 1096, fecha de consagración del altar por el Papa Urbano II en 1096. En ese momento ya estarían concluidos la cabecera y el transepto y se abrían iniciado las naves, por lo que la Porte de Comptes, situada en el brazo meridional del transepto, correspondería a esta primera fase constructiva. O. TESTARD. "La porte Miégeville de Saint-Sernin de Toulouse: proposition d'analyse iconographique". Mémoires de la Société Archéologique du Midi de la France, t. LXIII (2003), pp. 25-30 para el estado de la cuestión acerca de las cronologías de SaintSernin. También: Q. CAZES, D. CAZES. Saint-Sernin de Toulouse: de Saturnin au chef-d'oeuvre de l'art roman. Graulhet (Tarn), 2008. En el mismo caso nos encontramos con la Catedral de Jaca ya que su cronología también ha sido largamente discutida. En la actualidad, tras la expurgación documental realizada por A. Urbieto y los trabajos realizados por S. Moralejo, se piensa que los trabajos de la catedral de San Pedro se iniciaron durante el reinado de Sancho Rámirez (10631094) y ligados a diversas circunstancias: el establecimiento de un cabildo reformado, la creación del obispado de Jaca o la concesión del fuero a la ciudad en 1077. El clima reformista de su reinado aboga por la introducción del rito romano y el establecimiento de relaciones con el mundo transpirenaico y con Roma, algo que ya había sido impulsado durante el reinado de su padre Ramiro I. Prueba de ello es que el Monasterio de San Juan de la Peña es el primero en sustituir el rito hispánico por el rito romano según las indicaciones de la reforma cluniacense. Esta primera etapa se verá concluida hacia 1098 cuando tras la conquista de Huesca, Jaca perderá poco a poco su privilegiada situación, ya que la sede episcopal se traslada a la ciudad reconquistada que a partir de ahora se convertirá en el nuevo centro de poder del reino. I. BANGO TORVISO. El Camino de Santiago. Ed. Espasa-Calpe. Madrid, 1993, p. 90. Para un estado de la cuestión F. DE ASÍS 
la implantación del rito romano y en la expansión del léxico artístico del Románico, ya que los nuevos usos litúrgicos requieren nuevos tipos de edificios. Además y dentro del sistema moral que propugnaban, la peregrinación a los lugares santos ocupó un lugar destacado porque se entendió como demostración de una disposición penitente, de ahí el papel que desempeñaron también en la consolidación de los Caminos de Peregrinación, en especial el de Santiago de Compostela. Cluny va a jugar un papel primordial, porque su idea de que la salvación del alma exige la penitencia y el ascetismo afecta a todos, clérigos y laicos. La "tendencia moral reformadora" de esta orden tiene como objetivo prescribir a toda la sociedad una norma de vida que les garantizase la salvación por la voluntad de Dios y la misión de los monjes era dar ejemplo al pueblo, pueblo al que acabarán convenciendo del poder santificador de la penitencia y la ascesis. Uno de los principales esfuerzos de Cluny fue mantener vivos la conciencia del pecado, el arrepentimiento y el temor al castigo, agudizaron en los hombres la conciencia de la culpa para guiarlos hacia la humildad, la contrición y la penitencia. Por ello en sus sermones y escritos describían con una claridad elocuente el proceder pecaminoso y los castigos y tormentos del infierno intentando estremecer la fantasía y el alma de los hombres ${ }^{3}$. La obsesión de la Iglesia por aplicar sus propias limitaciones sexuales a los laicos va a propiciar además que el sistema de vicios

GARCÍA GARCÍA. "La portada occidental de la catedral de Jaca y la cuestión de las imágenes". Anales de Historia del Arte. Volumen Extraordinario (2010), pp. 69-89. En relación a Frómista su cronología dentro de la última década del siglo XI ya había sido apuntada por Serafín Moralejo quien vinculó su construcción a las empresas artísticas llevadas a cabo en el reinado de Alfonso VI. Es también la época de mayor actividad constructiva del Camino de Santiago y el momento en el que los cenobios cluniacenses de Tierra de Campos alcanzaron su mayor auge. Las aportaciones más recientes han fijado una fecha de referencia para el trabajo del escultor más importante del taller, el que realiza el conocido capitel inspirado en la Orestiada, vinculándolo a lo acontecido en torno a la celebración del Concilio de Husillos en 1088. Esta es por lo tanto la cronología de partida para el desarrollo del taller escultórico. Su construcción al hilo de la reforma litúrgica y sus vinculaciones con Cluny son aspectos que ya han sido tratados por otros autores. I. MORALEJO ALVÁREZ. "Cluny y los orígenes del románico palentino: el contexto de San Martín de Frómista". Jornadas sobre el arte de las Órdenes Religiosas en Palencia (Palencia, 1989). Palencia, 1990, pp. 7-33. Del mismo autor: "San Martín de Frómista en los orígenes de la escultura románica europea". Jornadas sobre el Románico en la provincia de Palencia (Palencia, 1985). Palencia, 1986, pp. 27-37. F. PRADO-VILAR. "Saevum Facinus: Estilo, Genealogía y Sacrificio en el Arte Románico Español". Goya, no 234 (2008), pp. 173-199. Del mismo autor y abordando aspectos de la escultura de Jaca y Frómista: "Del maestro de Orestes-Caín al maestro del sátiro: una conferencia sobre la belleza de la tragedia y la memoria del futuro". En: Maestros del románico en el Camino de Santiago. Fundación Santa María la Real. Aguilar de Campoo, 2010, pp. 11-46. M. POZAS YAGÜE. "Las portadas de los prioratos cluniacenses de Tierra de Campos en tiempos de Alfonso VI: una iconografía de corte monástico para una manifestación pública". Anales de Historia del Arte. Volumen Extraordinario 2 (2011), pp 267-270.

3. Un texto primordial para considerar todas estas cuestiones sigue siendo el de W. WEISBACH. Reforma religiosa y arte medieval. La influencia de Cluny en el Románico occidental. Ed. Espasa-Calpe. Madrid, 1949. Ver fundamentalmente pp. 25-26 y 87. 
y pecados surgido en un contexto claramente monástico se convierta en un sistema moral que debe reconducir y guiar los comportamientos de toda la sociedad medieval. En la difusión de esta mentalidad monástica se deben considerar aspectos que en mi opinión no se pueden obviar, como son el poder de seducción/repulsión de las imágenes, la valoración de la castidad y la virginidad y la visión que el pensamiento clerical, y mas específicamente el monástico, tienen de la unión carnal, de la sexualidad. De ahí la insistencia con la que intentan combatir sus perniciosos efectos ${ }^{4}$. Penitenciales tan conocidos como el del obispo Buscardo de Worms dedican sus capítulos más largos y completos a los pecados de la carne y sus consiguientes penitencias, recomendando a los confesores ser escrupulosamente precisos y exhaustivos en sus interrogatorios ${ }^{5}$.

Ahora bien, además de todos estos aspectos, se debe otorgar un papel muy destacado a la visión que la mentalidad medieval tiene del Pecado Original como un pecado sexual en el que Eva, la mujer, es la incitadora y la primera responsable. Todo ello confluye en una dirección clara, convertir a la mujer en sujeto tentador y a la vez objeto de la tentación porque va a prevalecer la ambivalencia del estamento clerical respecto a la mujer: la odian, la desprecian, pero sobre todo la temen, porque no pueden sustraerse a su encanto y se convierte en una especie de obsesión acuciante precisamente porque les está vedada, porque deben renunciar a ella en aras de una conducta ejemplar y evangélica ${ }^{6}$. Como ya ha sido señalado en otras ocasiones el monje va a ser el peor enemigo de la mujer "a la que utiliza como chivo expiatorio de sus propios fantasmas" ${ }^{\prime 7}$.

4. Recientemente M. POZAS YAGÜE. Las portadas... op. cit., pp. 251-279, ha puesto de manifiesto la relación entre la representación del binomio lujuria/avaricia y las empresas artísticas vinculadas a Cluny, señalando dichas imágenes como "exemplum monachorum" y describiéndolas como iconografía monástica, hipótesis que comparto aunque considero que sus destinatarios no eran únicamente los monjes, algo que matizaré más adelante. De todas maneras la vinculación con el ámbito monástico ya había sido reseñada por Emile Mâle y Werner Weisbach, autor al que ya he hecho referencia y que centra su obra, precisamente, en la influencia que ejerce Cluny en la creación y difusión de este tipo de motivos y quién en la p. 90 de su estudio refiere que uno de los objetivos de la figura de la femme-aux-serpents era despertar la mayor repugnancia posible y que para ilustrar la lujuria se creó un tipo iconográfico de un carácter extremadamente odioso.

5. J. HERRERA MARCOS. La lujuria en la iconografía románica. Cálamo. Palencia, 2011, pp. 79-98. Este penitencial fue redactado entre los años 1008 y 1012 . Acerca del tratamiento que las conductas sexuales tienen en los penitenciales ver: O. GIORDANO. Religiosidad popular en la Alta Edad Media. Madrid, 1983.

6. Para toda esta cuestión ver M. PILOSU. La Donna, la Lussuria e la Chiesa nel Medioevo. Edizioni culturali internazionale Genova. Génova, 1989, con numerosas referencias textuales destacando la I Parte: La donna tentatrice, pp. 25-67.

7. "El intento de una perfección espiritual que reniega de la existencia real de la carne, porque la considera esencialmente mala y generadora de pecado, facilita la presencia de obsesiones que incluyen especialmente la satisfacción natural del placer sensual. El primer protagonista en este mundo de tentaciones es la mujer, la que se ve, la que se sueña, la que no existe. Y en 
Los textos de la época insisten en la necesidad de que el hombre viva alejado de la mujer, inculcando incluso un cierto "miedo" y repulsión hacia el género femenino y advirtiendo del peligro de sus argucias para atraer a los hombres. Este es el contexto en el que se gestan las numerosas metáforas cargadas de significación negativa que ligan a las mujeres con el pecado, el mal y las fuerzas diabólicas ${ }^{8}$. A este respecto son muy ilustrativas las "delicadas" referencias con las que compara Odón de Cluny a las mujeres cuando dice: "la belleza física no va más allá de la piel. Si los hombres vieran lo que hay debajo de la piel, la mera vista de las mujeres les daría nauseas... Pero si nos negamos a tocar el estiércol o un tumor con la punta del dedo ¿cómo podemos desear besar a una mujer, un saco de heces?"9 . Destaco este fragmento del Abad de Cluny porque a mi juicio tanto la cronología como la procedencia del mismo nos ilustran acerca del contexto en el que se genera la presencia y la difusión de este motivo iconográfico en los programas escultóricos de los templos señalados.

ella se descargan las faltas y las desazones personales". J. YARZA LUACES. "De "casadas estad sujetas a vuestos maridos, como conviene en el Señor" a "Señora, soy vuestro vasallo, por juramento y compromiso". Actas de las III Jornadas de Investigación Interdisciplinar sobre la Mujer: La imagen de la Mujer en el Arte Español. Universidad Autónoma de Madrid, 1984, p. 54. También W. WEISBACH. Reforma religiosa... op. cit., p. 90 donde señala que en los monasterios y en un contexto de ascetismo severo el miedo a los demonios era alimentado por el miedo a la mujer como seductora para el pecado y para el placer prohibido de la carne en la creencia de que el demonio adoptaba, entre otras apariencias, también la de una mujer. En este sentido resulta muy ilustrativo el fragmento de un texto de Marborde, obispo de Rennes en el siglo XI cuando dice: "Entre las innumerables trampas que nuestro taimado enemigo ha tendido a través de las colinas y todas las llanuras del mundo, la peor y la que casi nadie puede evitar es la mujer, funesto cepo de desgracia, vástago de todos los vicios, que ha engendrado en el mundo entero los escándalos más numerosos... La mujer, dulce mal, a la vez panal de cera y veneno, que con espada untada en miel atraviesa el corazón mismo de los sabios". E. ARAGONÉS ESTELLA. La imagen del Mal en el románico navarro. Gobierno de Navarra. Pamplona, 1996, p. 140.

8. M. I. DEL VAL VALDIVIESO. "El Mal, el Demonio, la Mujer (en la Castilla Bajomedieval)". En: Vivir siendo mujer a través de la Historia. Coord. M. ${ }^{a}$ I. del Val, C. de la Rosa, M. J. Dueñas. Universidad de Valladolid, 2005, pp. 13-40. También A. TOLDRÁ I VILARDELL. Asmodeu. Dona, dimoni y sexe a l'edat mitjana. Universitat de Valencia, 2011, pp. 29-62.

9. San Oddonis Abbatis Cluniacensis Collationes. Liber II, cap. IX. Las Collationes del abad de Cluny, redactadas en el siglo $X$ son tres libros de ensayos morales sobre las virtudes, los males de su tiempo y la meditación espiritual. Tienen como modelo las de Juan Casiano y fueron muy estimadas durante la Edad Media. Ver: I. ROSE. Construire une société seigneuriale: itinéraire et ecclésiologie de l'abbe Odon de Cluny (fin du IXe - milieu du Xe siécle). Brepols, Turnhout, 2008. Recogen también este texto: E. BORNAY. Las hijas de Lilith. Ensayos Arte Cátedra. Madrid, 2004, p. 44. M. ․ P. CARRILLO LISTA, J. R. FERRÍN GONZÁLEZ. "Algunas representaciones de vicios en el románico gallego: la lujuria". Anuario Brigantino, no 19 (1996), p. 237. A. GÓMEZ GÓMEZ. El protagonismo de los otros. La imagen de los marginados en el arte románico. Bilbao, 1997. p. 55. F. COLIN-GOGUE. L'image... op. cit., p. 73. M. POZAS YAGÜE. "Las portadas..." op. cit., p. 277. De la misma autora: "La Lujuria". Revista Digital de Iconografía Medieval, vol. II, no 3 (2010), p. 35 . 
No voy a pronunciarme sobre el posible origen languedociano, borgoñón o hispano del motivo ${ }^{10}$ ni tampoco sobre la conocida polémica en torno a la prioridad de lo francés sobre lo hispano o viceversa. No es el propósito de esta aportación y existe una abundante bibliografía sobre esta cuestión. Ya he señalado que uno de los grandes esfuerzos de Cluny fue mantener vivos la conciencia del pecado, el arrepentimiento y el miedo al castigo y que por ello describían con una gran elocuencia los tormentos del infierno. Este es sin lugar a dudas uno de los principales objetivos de la femme-aux-serpents, impactar al auditorio al que va dirigida y hacerlo a través de una imagen rotunda, que active los cinco sentidos de quien la contempla.

Pero ello no explica por si solo su extraordinaria difusión. Por mucho que la Lujuria sea uno de los pecados más combatidos debe haber alguna otra razón que ayude a comprender porque la femme-aux-serpents se utiliza no sólo como imagen singular y específica de un pecado concreto sino también del pecado en sí, del pecado con mayúsculas. Y aquí la reforma benedictina va a jugar un papel fundamental porque promueven y difunden el imaginario asociado a los pecados y tormentos del infierno no sólo como mensaje claramente disuasorio, sino también como instrumento didáctico, utilizando estas imágenes como antítesis de los pasajes evangélicos para ilustrar de manera clara la verdad que contienen las Sagradas Escrituras.

A finales del siglo XI, hacia 1084, el monje Guibert de Nogent recomendaba a los clérigos el empleo de analogías y oposiciones para explicar la escritura santa. Su pequeño tratado titulado Liber quo ordine sermo fieri debet va a servir durante mucho tiempo de guía para los predicadores. Dividido en tres partes, en la segunda explica las cualidades de un buen sermón y cómo los textos de la Escritura se deben comentar realizando una aproximación didáctica (tropológica) y alegórica, además de histórica y anagógica. En la tercera parte recomienda que los predicadores incidan en temas como los vicios y las virtudes y el cielo y el infierno ${ }^{11}$.

En este sentido el programa escultórico de la girola de la Catedral de Santiago se ha interpretado como Speculum Monachorum, ya que el discurso

10. Emile Mâle apostó por el origen languedociano, Werner Weisbach por el borgoñón y Meyer Schapiro por situar los ejemplos más antiguos en España y el suroeste de Francia.

11. También y siguiendo la tradición que desde la Tardoantigüedad recomienda el uso de exempla en la literatura homilética, se manifiesta en estos términos: "Placere enim nonnullis comperimus simplices historias et veterum gesta sermoni inducere et his omnibus quasi ex diversas picturam coloribus adornare". (col. 25). J. TH. WELTER. L'Exemplum dans la littérature religieuse et didactique du Moyen Age. Bibliothéque d'histoire ecclésiastique de France. E. H. Guitard. París-Toulouse, 1927, pp. 35-36. A Guibert de Nogent se refiere también TH. W. LYMAN. "Motiv et narratif. Vers une tipologie des themes profanes dans la sculpture monumentale de Las Romerías". Cahiers de Saint Michel de Cuxa, no 10 (1979), p. 75. 


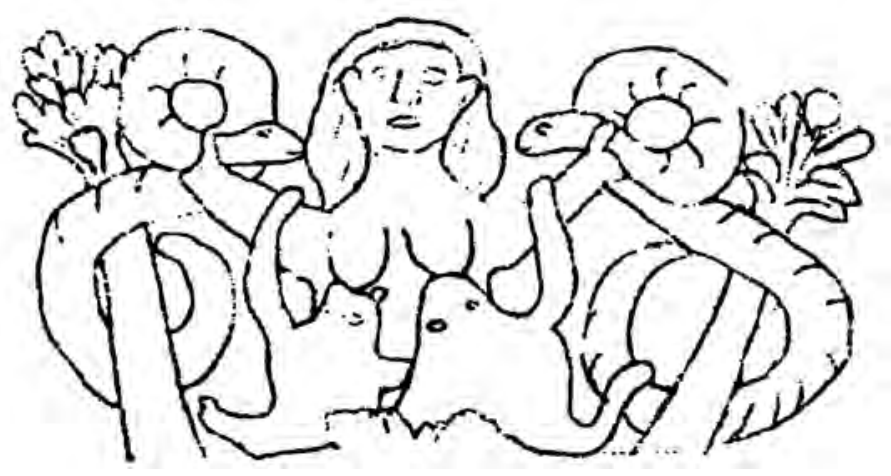

Figura 1. Dibujo del capitel de la girola de la Catedral de Santiago de Compostela. Victoriano Nodar Fernández (2002).

figurativo se acerca a la estructura de un sermón y toma un carácter claramente homilético. A través de un repertorio básicamente animalístico se intentan transmitir determinados ejemplos moralizantes, ya que las ideas que subyacen bajo estas representaciones se han vinculado a la vigilancia y a la lucha contra el pecado, así como a la necesidad de la renovación a través del arrepentimiento y la penitencia ${ }^{12}$. Es precisamente en el conjunto de imágenes asociadas al pecado y a las argucias del diablo donde se inserta la representación de la femme-aux-serpents ${ }^{13}$ (Fig. 1). El capitel, que pertenece a la primera fase constructiva de las obras iniciada ca. 1075-1077 está situado en una ventana abierta entre las capillas del Salvador y de San Pedro. La imagen nos ofrece la figura de una mujer desnuda con gesto de pavor y dolor que intenta sujetar con sus brazos a las dos serpientes que se acercan a sus orejas mientras dos sapos le succionan los senos. Las dos serpientes que ocupan los laterales del capitel trepan por sendos árboles, detalle que ha llevado a relacionar esta imagen de Santiago con algunas ilustraciones de los Exultet, en concreto con el Barb.Lat. 592 de la Biblioteca Apostólica Vaticana y procedente de Montecassino ${ }^{14}$. Datado entre 1058 y 1087 la representación de la Tierra-Madre aparece surgiendo de una colina flanqueada por dos árboles y amamantando a un buey y a una serpiente. La evolución desde la representación de Tellus, la Tierra-Madre, a la imagen de la Lujuria se ha fundamentado también en su vinculación con diversos aspectos presentes en el Pecado Ori-

12. V. R. NODAR FERNÁNDEZ. "La cabecera de la Catedral de Santiago: un espacio abierto a la comunidad de Antealtares". En: III Congresso Internacional de Associaçao Portuguesa de Historiadores del Arte. Coimbra, 2006, pp. 1-14.

13. Ídem. Entre las representaciones de los capiteles de la girola vinculadas al pecado destacan las arpías, el zorro acechando aves, un monje torturado por dragones o un sonador de cuerno.

14. El Canto de la Vigilia Pascual toma su nombre precisamente de las primeras palabras del texto "Exultet iam angelica turba coelorum" que se cantaba en la mañana del sábado de 
ginal ${ }^{15}$. Para Victoriano Nodar los receptores fundamentales de esta imagen serían los monjes benedictinos de Antealtares que utilizaba una parte de la cabecera como iglesia y que eran los encargados de realizar el culto apostólico tras la firma del documento de concordia en 1077. La presencia de la femme-aux-serpents se inserta aquí en un discurso figurativo claramente disuasorio y por lo tanto contundente ante el peligro que suponen la tentación y los pecados de la carne, sobre todo para una comunidad monástica.

Ahora bien, ya he apuntado a lo largo de estas páginas que uno de los factores que rodean la creación y difusión de este motivo iconográfico es precisamente la visión que la mentalidad monástica tiene de las relaciones carnales en general y de la mujer en particular, así como la insistencia con la que intentan transmitir estas ideas a la sociedad laica. Por ello, y aunque no dudo de que en primera instancia el auditorio de la imagen de Santiago fuera monástico, es muy breve el espacio de tiempo en el que la femme-auxserpents da el salto a emplazamientos no tan restringidos y mucho más accesibles a las miradas de todos.

Lyman señala que el espíritu popular retuvo o reservó el nombre de "puerta de los pecados capitales" para la Porte des Comtes de Saint-Sernin de Toulouse. La doble portada, cuya construcción ya estaba en marcha hacia 1080, presenta ocho capiteles que corresponden a las columnas en que apoyan las arquivoltas. El ciclo iconográfico tiene como tema fundamental la parábola bíblica del pobre Lázaro y el hombre rico, el rico Epulón, y se complementa con el castigo o tormento a distintos pecadores. Siguiendo el relato evangélico vemos en uno de los capiteles al hombre rico sentado ante una mesa porque "todos los días celebraba espléndidos banquetes" y al pobre Lázaro en un lateral de la escena ya que "saciaba su hambre con lo que tiraban de la mesa del rico". Otro de los capiteles nos muestra la recompensa de Lázaro: su alma, en forma de pequeña figurita desnuda, aparece en una mandorla portada por ángeles: "un día el pobre murió y fue llevado por los ángeles al seno de Abraham". El rico también murió pero fue directo al abismo para ser atormentado durante toda la eternidad porque ya había recibido sus bienes en vida ${ }^{16}$. Los tormentos

Pascua. Solía estar escrito e iluminado en rollos recogiendo la influencia del Rollo de Josué realizado en Constantinopla a mediados del siglo X. En los Exultet la Tierra-Madre, imagen de la fecundidad que da alimento a todas las criaturas, se convierte en la alegría de la Naturaleza ante la Resurrección de Cristo.

15. V. R. NODAR FERNÁNDEZ. "De la Tierra-Madre..." op. cit. pp. 338-344. En este sentido se debe reseñar que el artículo de este autor sigue la estela del estudio, ya clásico, de J. LECLERCQ-KADANER. "De la Terre-Mére á la Luxure. À propos de "La migration des symboles". Cahiers de Civilisation Médiévale, XVIII (1975), pp. 37-43, quien ya apuntaba la influencia de las miniaturas de los Exultet en la evolución desde las representaciones de la Tierra-Madre a las de la femme-aux-serpents como castigo a la lujuria.

16. Lucas 16, 19-31. La parábola del pobre Lázaro aparece por primera vez en el Evangelio de Liuthar conservado en Aix-la-Chapelle. A partir de ese momento su representación se 
del hombre rico se ven acompañados por las imágenes de otros pecadores: hombres atacados por demonios, dragones o monstruos alados y la representación del castigo de la Avaricia, que junto al de la Lujuria es uno de los más difundidos durante toda la Edad Media ${ }^{17}$. En uno de los capiteles del lado izquierdo del pilar central es donde aparece la imagen de una mujer desnuda atormentada por serpientes que reptan por su cuerpo y le muerden los senos mientras dos mujeres vestidas contemplan horrorizadas su suplicio (Fig. 2).

difundirá de manera significativa durante los siglos XI y XII. Ver: J. BASCHET. Le sein du pére. París, 2000, p. 394. El dato lo recoge P. RODRÍQUEZ BARRAL. "Reflexiones sobre el castigo de la avaricia y la lujuria a propósito de su representación en la escultura románica catalanoaragonesa". Codex Aquilarensis, no 21 (2005), p. 11. Nota 12. A estos capiteles de la Porte des Comtes se refieren entre otros muchos: W. WEISBACH. Reforma religiosa... op. cit., pp. 92-93. TH. W. LYMAN. Vers une typologie... op. cit., pp. 67-78. Del mismo autor: "The Sculpture Programme of the Porte des Comtes Master at Saint-Sernin in Toulouse". Journal of the Warburg an Courtauld Institutes, XXXIV (1971), pp. 12-39. M. DURLIAT. "Les origines de la sculpture romane á Toulouse et á Moissac". Cahiers de Civilisation Médiévale, XII (1969), p. 352. La parábola del pobre Lázaro y el rico Epulón asociada a la representación de la lujuria y la avaricia se utilizará también como discurso figurativo en la portada de Moissac a comienzos del siglo XII. Puesto que la bibliografía acerca de esta abadía desborda los objetivos de este estudio tanto por cronología como por número, me limito a señalar algunas de las aportaciones más recientes: I. H. FORSYTH. "Narrative at Moissac: Schapiro's Legacy". Gesta, XLI/2 (2002), pp. 71-93. A. LUYSTER. "The Femme-aux-Serpents at Moissac: Luxuria (Lust) or a Bad Mother?" En Between Magic and Religion: Interdisciplinary Studies in Ancient Mediterranean Religion and Society. Eds. S. A. SIRVATHAM, C. O. PACHE, J. WARTROUS. Rowman \& Littlefield Publishers. Oxford, 2001, pp. 165-191.

17. La fórmula iconográfica más difundida para representar el castigo a la avaricia es la de un personaje masculino casi ahogado por la pesada bolsa que le cuelga del cuello y que en ocasiones también está siendo atacado por diferentes monstruos o por demonios. La referencia a la bolsa y su asociación a la avaricia ya figura en la Psicomaquia de Prudencio al relatar su enfrentamiento con la Caridad. La advertencia contra estos dos vicios aparece en San Pablo, Efesios 5,3 "Fornicatio autem et omnia immunditia aut avaritia nec nominetur in vobis, sicut decet sanctos" (En cuanto a la lujuria o cualquier clase de impureza o avaricia, que ni siquiera se nombren entre vosotros, pues así corresponde a creyentes). La difusión del binomio Avaricia/Lujuria en la iconografía medieval es un aspecto que ha sido tratado en numerosos estudios centrados en esta temática por lo que me limito a citar algunos de los más significativos: L. K. LITTLE. "Prides Goes before Avarice: Social Change and the Vices in Latin Christedom". The American Historical Review, vol. 76, no 1 (1971), pp. 20-23. J. MARTIN-BAGNAUDEZ. "Les représentations romanes de l'avare. Etude iconographique". Revue d'histoire de la spiritualité, 50 (1974), pp. 397-432, sigue siendo un artículo de referencia para este tema. También E. ARAGONÉS ESTELLA. La imagen del Mal... op. cit., pp. 159-165. A. GÓMEZ GÓMEZ. El protagonismo... op. cit., pp. 23-53. P. RODRÍGUEZ BARRAL. "Reflexiones..." op. cit., pp. 6-28. M. F. CUADRADO LORENZO. "Tres esculturas de Leire y sus relaciones con temas escatológicos". Príncipe de Viana, no 199 (1993), pp. 229-245. P. L. HUERTA HUERTA. "Las visiones infernales: Pecados, pecadores y tormentos". En: Poder y seducción de la imagen románica. Aguilar de Campoo, 2006, pp. 81-116, y sobre todo pp. 94-97. I. MONTEIRA ARIAS. "Las formas del pecado en la escultura románica castellana. Una interpretación contextualizada en relación con el Islám". Codex Aquilarensis, no 21 (2005), pp. 51-83. 
Figura 2. Capitel de la Porte des Comtes de Saint-Sernin de Toulouse. Fuente: http://lieuxsacres. canalblog.com.

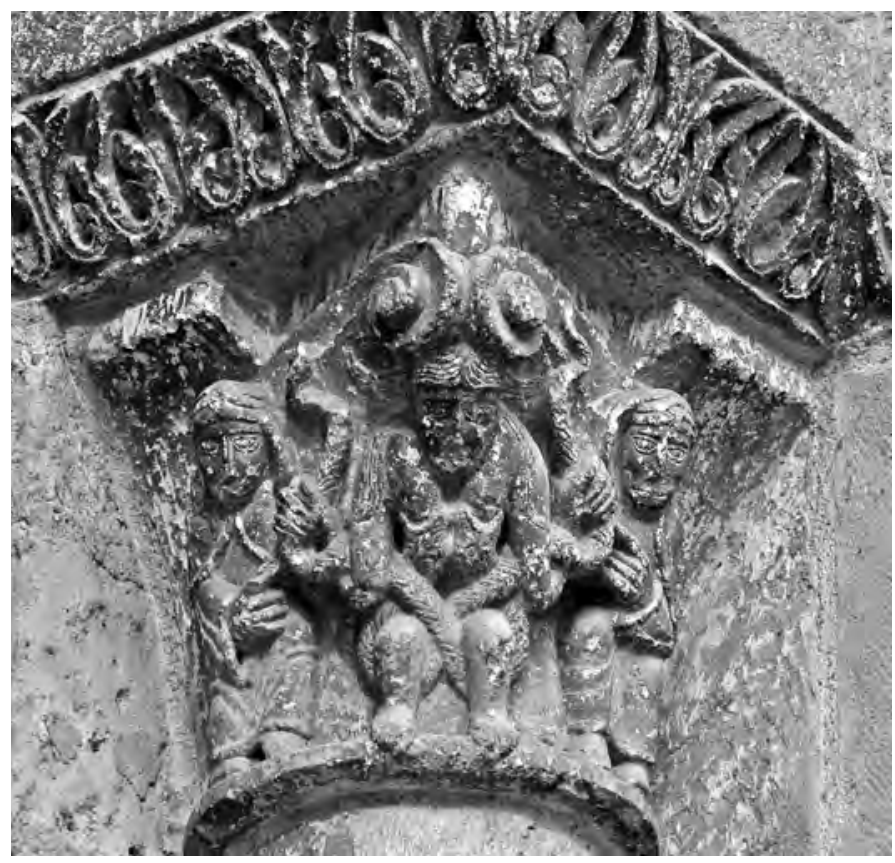

En la iconografía de las portadas del lado meridional de Saint-Sernin, Porte des Comtes, abierta en el transepto, y Porte Miégeville, en mitad de la nave, se ha visto latir la atmósfera de los concilios celebrados en 1056 y 1060-61. En ellos se condenaba la simonía y el nicolaísmo, dos de las faltas más perseguidas por la reforma gregoriana y por Cluny y que en el fondo no dejan de ser una fórmula reelaborada para los eclesiásticos de los pecados de avaricia y lujuria ${ }^{18}$. Ahora bien si consideramos el emplazamiento de estos motivos, las portadas, la advertencia parece clara y rotunda para todos, porque las normas y prohibiciones estipuladas para monjes y clérigos en los Concilios tienen su versión laica en las que los predicadores lanzan a los fieles en sus sermones ${ }^{19}$

18. O. TESTARD. La porte Miégeville... (op. cit., nota 103) p. 27. La simonía es la falta estipulada para los clérigos que negocian, compran, venden y trafican con cargos y oficios eclesiásticos para obtener un beneficio económico. El nicolaísmo por su parte alude a la inobservancia de los preceptos vinculados con la castidad y el celibato, dos problemas que preocupaban mucho a la Iglesia a tenor de las reiteradas alusiones y condenas que se realizan en los Concilios. A ello se refiere M. POZA YAGÜE. "Las portadas..." op. cit., p. 263 para fundamentar su hipótesis en torno a Frómista y Dueñas pero sin advertir la alusión a ambas faltas en el programa iconográfico de las portadas de Saint-Sernin.

19. La presencia de las dos mujeres vestidas contemplando el castigo de la Lujuria se ha visto como representación del auditorio de un sermón eclesiástico que en este caso se incluye en el 
y aunque destinarios y fórmulas de persuasión sean distintas al final lo que prevalece es el mensaje que se transmite: aquellos que optan por disfrutar sin medida de los placeres terrenales y abrazan la concupiscencia, sea carnal o material, sufrirán lo mismo que el rico Epulón. La estrategia figurativa pasa por confrontar recompensa y castigo oponiendo la figura del pobre Lázaro ascendiendo a los cielos a las imágenes vinculadas a la esfera de lo pecaminoso e infernal representadas a través de diversos suplicios corporales. Y entre ellos los dos más elocuentes, lujuria y avaricia, convertidos ya en el binomio predilecto para aglutinar todos los demás y convertirse en imagen del pecado por antonomasia ${ }^{20}$.

En la iglesia de San Martín de Frómista dicho binomio se duplica, ya que aparece en el interior y en el exterior de la iglesia. Serafín Moralejo destacó la estricta contemporaneidad y los notables paralelismos con el programa desarrollado en la primera campaña de Saint-Sernin de Toulouse y en concreto con la imaginería de los capiteles de la Porte des Comtes ${ }^{21}$. El primer binomio de la lujuria y la avaricia figura en un capitel de la jamba izquierda de la portada septentrional. A pesar de su deterioro se ha reconocido el esquema iconográfico habitual de dichas representaciones: el avaro con la bolsa al cuello y junto a un

propio exemplum, siendo partícipe de él. V. NODAR FERNÁNDEZ. "De la Tierra-Madre..." op. cit., pp. 345-346, quien sin embargo señala como destinatarios fundamentales de la imagen a los canónigos de Toulouse en el contexto del interés que tienen los programas reformistas por combatir determinados vicios como la lujuria y la avaricia en el seno de comunidades religiosas.

20. Mientras que el resto de los castigos corporales son más complicados de asignar a un pecado concreto, las fórmulas iconográficas del castigo a la lujuria y a la avaricia van a tener una fortuna figurativa indiscutible, por lo que su difusión va a propiciar una rápida identificación y comprensión de la imagen por todos. Sabemos además que ambos vicios son objetivo fundamental en el combate eclesiástico contra el pecado y figuran, además de en las cartas paulinas, en el esquema de las tres tentaciones basado en la primera epístola de San Juan: "porque todo lo que hay en el mundo -los apetitos desordenados, la codicia de los ojos y el afan de grandeza humana- no viene del Padre, sino del mundo" (I Jn 2,16), considerada más bien una homilía que una carta, de ahí que se utilizará fundamentalmente en lo pastoral. En ella lujuria, avaricia y soberbia son el foco de atención prioritario, caracterizados como concupiscencia de la carne, concupiscencia de los ojos y orgullo de la vida. C. CASAGRANDE, S. VECCHIO. "Pecado" En: Diccionario razonado del Occidente Medieval. J. LE GOFF, J. C. SCHMITT. Ed. Akal. Madrid, 2003, p. 642. Dato recogido por P. RODRÍGUEZ BARRAL. "Reflexiones..." op. cit., p. 12. Para Honorio de Autun Lujuria y Avaricia son pecados insaciables por lo que quienes los cometen merecen la condenación eterna: "Sanguisuga diabolus est, qui semper sanguisinem sitit hoc est ad peccata homines trahere cupit, et sitim peccandi incessanter accendit. Quae sunt illae sanguisugae duae, dicentes: Affer, affer, et numquam saturantur? Luxuria et avaritia; nam quanto magis quisque luxuriatur, tanto amplius delectatur. Similiter quanto quisque sibi divitias cumulat, tanto magis semper augmentare desiderat". HONORIUS D'AUTUN. Quaestiones in proverbia, ch. XXX; P.L. 172, 328 A-B. En J. MARTIN-BAGNAUDEZ. "Les representations..." op. cit., pp. 419-420.

21. S. MORALEJO ALVÁREZ. "Cluny y los orígenes del románico palentino: el contexto de San Martín de Frómista". Jornadas sobre el arte de las Órdenes Religiosas en Palencia (Palencia, 1989), Palencia, 1990. p. 23. Nota 35. 
Figura 3. Capitel de la nave de San Martín de Fromistá. Fuente: http://www.flickr.com/ photos/rabiespierre/

2347255295; http:// amigosdelromanico.org/ phpBB.

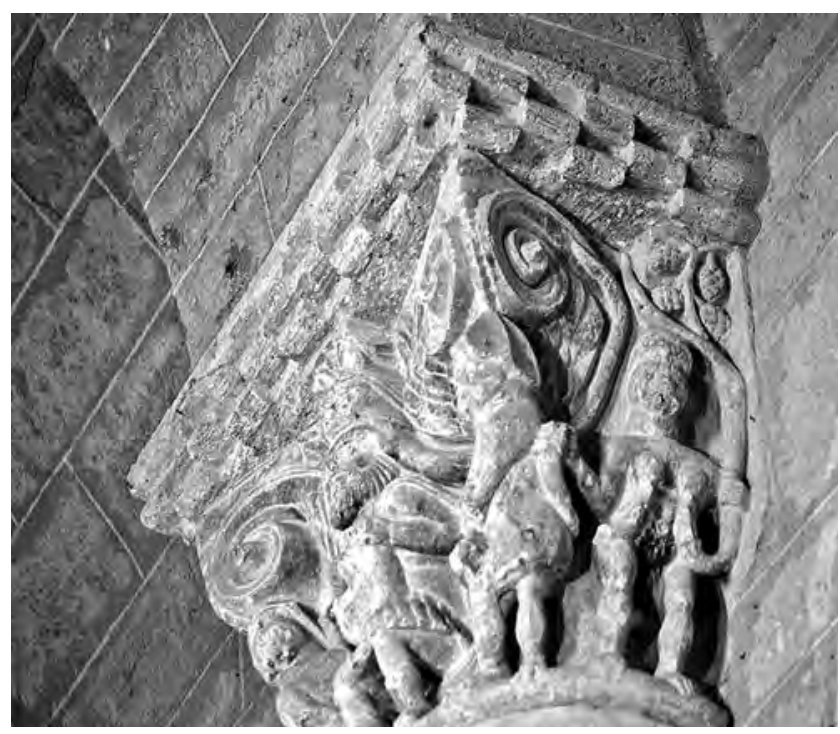

ser demoníaco situado a su izquierda y una figura femenina sentada y vestida a la que dos serpientes le muerden en el pecho ${ }^{22}$.

Más elocuente es el capitel del interior, situado en la nave del Evangelio y frontero precisamente con la puerta norte. (Fig. 3) En la cara mayor del capitel una figura masculina barbada sujeta con sus manos las correas de la bolsa que le cuelga del cuello. Aparece flanqueado por dos figuras demoníacas desnudas y aladas mientras que un ser monstruoso situado sobre él parece estar devorándole la cabeza, En los lados menores del capitel y por partida doble dos mujeres desnudas son atormentadas por serpientes que se enroscan en su cuerpo y les muerden los senos mientras ellas intentan apartarlas con sus manos ${ }^{23}$. Moralejo resaltó el hecho de que algunas secuencias programáticas se ubicaran precisamente en puntos de acceso, como el arco que separa la nave del transepto y ante dos de las portadas. Es en estos lugares estratégicos donde se representa la caída del hombre y sus consecuencias, los comportamientos pecaminosos que se deben evitar y corregir. Además de la avaricia y la lujuria identifica la

22. M. POZA YAGÜE. "Las portadas..." pp. 268-269.

23. Ídem. pp. 267-268 para la descripción de los motivos. El esquema icnográfico utilizado es muy similar a la imagen de Compostela y a la del Panteón de San Isidoro de León que será reseñada más adelante. En todas ellas las lujuriosas intentan apartar o separar de su cuerpo a las serpientes sujetándolas con sus manos. En Saint-Sernin sin embargo la lujuriosa parece estar resignada a su suerte, ya que sus brazos descansan sobre el regazo y no realiza ningún gesto intentando evitar el suplicio. 
soberbia, la violencia y la discordia, conductas que son continuamente reprobadas en la pastoral de la reforma ${ }^{24}$. En el caso concreto de la lujuria señala como precedentes en lo hispano las imágenes de Compostela y el Panteón de San Isidoro, lo que coincide con las propuestas más recientes para la cronología de este templo que sitúan el desarrollo de su fábrica en relación a la celebración del concilio de Husillos en 1088.

Ya he señalado que una de las últimas aportaciones realizadas en relación al binomio lujuria y avaricia de Frómista considera estas representaciones como exemplum monachorum y por lo tanto destaca como principales destinatarios de la admonición al público eclesiástico. Coincido con la idea de que la representación de la lujuria se podría considerar "iconografía monástica", pero no comparto la tesis de que los monjes y clérigos sean los receptores prioritarios de estas advertencias. Marta Poza sostiene que en las portadas monásticas, y entiendo que por extensión también en el interior de los templos, lo que se representa es el castigo con la amenaza del Juicio y el Infierno, mientras que en los templos parroquiales y pequeñas ermitas se prefiere figurar el delito mismo y no su condena con un significado mas admonitorio y moralizador que punitivo ${ }^{25}$. En mi opinión ambas cuestiones van de la mano, se muestra lo punitivo precisamente como admonición y advertencia, algo muy presente en los sermones y discursos figurativos vinculados a Cluny como ya he señalado. Además, no hay nada más que recopilar el elevado número de representaciones de la femme-aux-serpents a lo largo del siglo XII y en todo tipo de templos y emplazamientos para darse cuenta del interés por mostrar precisamente el castigo, puesto que así el impacto es mucho más rotundo ${ }^{26}$. En relación a los destinatarios creo que abarca a los dos

24. Para S. MORALEJO ALVÁREZ. "Cluny y los orígenes." op. cit., p. 22 la avaricia y la lujuria se localizan en la arcada misma que constituiría el "pórtico interno" de la portada septentrional, portada en la que se reitera el binomio. Por su parte F. PRADO-VILAR. "Saevum Facinus..." op. cit., p. 183, recoge lo indicado por Moralejo señalando que "en el arco interno de la entrada septentrional (que servía de acceso a los laicos) se representan fábulas y temas moralizantes condenando pecados "urbanos" como la avaricia y la lujuria...".

25. Los temas que en su opinión figuran en templos parroquiales o pequeñas iglesias con un sentido moralizador serían los exhibicionistas de ambos sexos, las parejas besándose o manteniendo relaciones sexuales, los personajes itifálicos, etc. También apunta que el esquema iconográfico clásico del binomio lujuria/avaricia no se difunde por las portadas de los templos parroquiales o catedralicios hasta mediados del siglo XII. Ver pp. 273-274 de su estudio. Ante esta reflexión planteo el caso de la Portada des Comtes, ya que siendo Saint-Sernin un templo también vinculado a la influencia de Cluny y sus canónigos, canónigos regulares de San Agustín, la imaginería de sus portadas estaba a la vista de todos puesto que Saint-Sernin estaba en el centro de la villa de Toulouse.

26. En este sentido sigue siendo de extraordinaria utilidad el catálogo de imágenes constatadas por A. WEIR, J. JERMAN. Images of Lust... op. cit., en el que además se incluyen mapas de Irlanda, Inglaterra, Norte de la Península y Francia con la distribución geográfica de los distintos motivos que aluden a la lujuria, incluido lógicamente el de la femme-aux-serpents. 
órdenes que alberga la casa de Dios, clérigos y laicos, y las razones para ello han sido presentadas a lo largo de todo este estudio. Creo que dirigir la admonición hacia unos grupos determinados en detrimento de otros no era precisamente el objetivo de la lucha contra el pecado. Es posible que el desarrollo urbano y comercial de las villas y la progresiva secularización de la sociedad pueden estar detrás de la gran difusión de estos motivos ${ }^{27}$, pero de ahí a considerar como destinatarios primordiales o bien a monjes o clérigos $^{28}$, o bien a laicos, incluidos por supuesto los nobles ${ }^{29}$, o bien a peregrinos ${ }^{30}$ no pienso que sea la cuestión fundamental. Cada caso concreto puede obedecer a circunstancias distintas, pero como he señalado es la lucha contra determinados comportamientos pecaminosos y las estrategias semánticas y figurativas que se despliegan para conseguirlo lo que realmente prevalece detrás de todas estas representaciones.

Con un esquema iconográfico muy similar, la imagen del castigo a la lujuria del Panteón de San Isidoro de León se presenta de manera singular, sin la compañía de la avaricia ni de otros motivos que en principio parezcan aludir al pecado y su condena. En su momento Meyer Schapiro consideró que era la primera representación hispana, datándola en 1063 y planteando la dificultad de

27. M. SCHAPIRO. "From Mozarabic to Romanesque in Silos". The Art Bulletin, vol. XXI (1939), pp. 312-374. Edición española en: Estudios sobre el románico. Madrid, 1984. pp. 37 120, fundamentalmente pp. 49-50, fue el primero en señalar que el favor iconográfico que tuvieron la lujuria y la avaricia en el Románico era la respuesta eclesiástica al desarrollo de una sociedad cada vez más urbana y comercial y que uno de lo ejes privilegiados de este desarrollo era precisamente el Camino de Santiago.

28. Esa es la opinión manifestada por V. R. NODAR FERNÁNDEZ. "De la Tierra-Madre..." op. cit. y M. POZA YAGÜE. "Las portadas..." op. cit.

29. Siguiendo la estela de Schapiro e incluyendo a la clase nobiliaria, en la que Cluny y otras congregaciones tuvieron sus mayores benefactores después de la realeza S. MORALEJO ÁLVAREZ. "Cluny y los orígenes..." op. cit., p. 24. Por su parte T. MARTIN. "Escultura románica para un público laico: el "maestro de la Orestiada" de Frómista y sus contemporáneos". En: San Martín de Frómista, ¿paradigma o historicismo? Valladolid, 2005, pp. 72-73 opina en relación a la representación de los vicios y en concreto a las escenas alusivas a lo sexual que aunque dirigidas por los religiosos su finalidad es un ejemplo moralizante para los laicos, puesto que los monjes tenían muy presente a qué habían renunciado, voto de castidad, pobreza y obediencia, y lo que querían era que los demás también rechazaran las tres grandes tentaciones. Aunque comparto su idea de que lujuria, avaricia y soberbia eran los tres grandes vicios a combatir, incluyo también como receptores a los religiosos porque la suya era una lucha constante y continuada por mucho que tuviesen muy claros los votos que habían realizado. En este sentido un sermón de Étienne Langton, maestro de Teología en París hacia 1180, en el que predicaba contra la lujuria y la avaricia parece que tenía como destinatarios principales a clérigos, monjes, prelados y estudiantes de Teología. J. LONGÉRE. Oeuvres oratoires de maîtres parisiens au XIle siécle. Étude historique et doctrinale. 2 vols. París, 1975. (vol. II. p. 150. Nota 90 y vol. I. p. 29). Dato recogido por M. POZA YAGÚE. Las portadas... op. cit., pp. 275-276. Nota 53.

30. Recientemente J. WILLIAMS. "Framing Santiago". En: Romanesque Art and Thought in the Twelfh Century. Essays in Honor of Walter Cahn. Ed. C. HOURIHANE. Princeton, 2008, pp. 219-238, refiriéndose a la Porte des Comtes de Toulouse. 


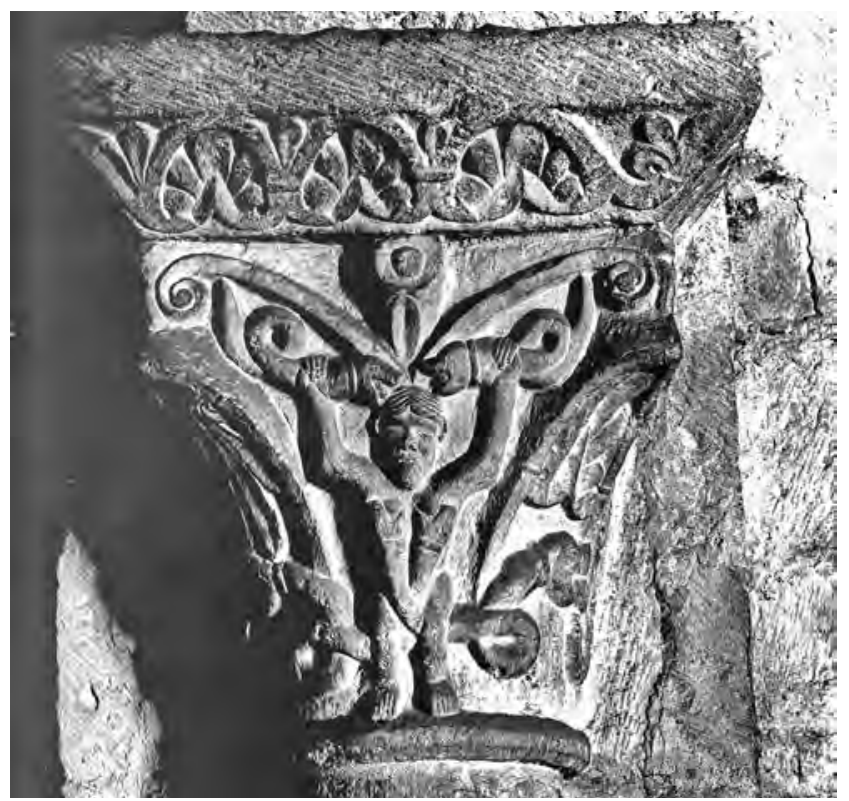

Figura 4. Capitel

del Panteón de

San Isidoro de León.

Archivo Zodiaque.

establecer el origen de esta iconografía entre ambos países ${ }^{31}$. Hoy sabemos que su cronología es algo posterior, ca. 1080 y por lo tanto contemporánea a las que en este estudio se están destacando. El Panteón es una estructura de planta cuadrada y abovedada situada en el lado occidental de la iglesia de San Isidoro a la que se adosa a través de su muro oriental. Por eso se conoce también con el nombre de nártex, pórtico occidental o capilla de Santa Catalina ${ }^{32}$.

El relieve está tallado en un capitel del lado occidental del Panteón, lado que se abre hacia la muralla mediante una arquería de tres vanos y en concreto en el paño que forra el parapeto romano ${ }^{33}$ (Fig. 4). Se trata de una figura desnuda que levanta los brazos para sujetar dos serpientes que parecen morderle la cabeza mientras otras dos reptan por su cuerpo hasta morderle los senos ${ }^{34}$. El conjunto de capiteles que rodean la representación del castigo a la lujuria

31. M. SCHAPIRO. From Mozarabic... op. cit.

32. A. VIÑAYO GONZÁLEZ. Real Colegiata de San Isidoro. El tesoro de León. Edilesa. León, 2000, p. 15.

33. G. BOTO VARELA. "In Legionessy..." op. cit., p. 130, Nota 46.

34. En relación al género de la figura desnuda su anatomía es femenina puesto que las serpientes le muerden los senos, pero el rostro es bastante indefinido y para algunos investigadores masculino e incluso barbado. Así lo manifiestan: A. GÓMEZ GÓMEZ. El protagonismo... op. cit., p. 62, y también M. POZA YAGÜE. Las portadas..., p. 269, nota 32, quien señala características similares para la lujuriosa esculpida en la portada de la iglesia de San Martín de Frómista. 
muestra motivos vegetales y animales como cabezas de perros o lobos y hacia el ángulo noroeste temas veterotestamentarios: Moisés con las tablas de la Ley, el sacrificio de Isaac o la burra de Balaam ${ }^{35}$. Sin entrar a valorar las distintas interpretaciones que se han realizado en torno a las diversas funciones que pudo haber tenido esta estructura ${ }^{36}$, solo señalar que de nuevo encontramos en un mismo espacio pasajes bíblicos contrapuestos a escenas que ilustran la condena a los pecadores. En este sentido y considerando únicamente los motivos escultóricos, los temas neotestamentarios aparecen representados en el lado oriental y en las cestas que flanquean la puerta, hoy tapiada, de entrada a la iglesia de San Isidoro. Se trata de la Resurrección de Lázaro y de la Curación del leproso, considerados por su cronología de los primeros en representar epi-

35. VV.AA. Enciclopedia del Románico en Castilla-León. Vol. I: León. Fundación Santa María la Real. Aguilar de Campoo, 2002, pp. 553-612. A. VIÑAYO GONZÁLEZ. Real Colegiata... op. cit., pp. 15-18. Para G. BOTO VARELA. "In Legionessy..." op. cit., p. 120, una parte importante del repertorio esculpido sería de cuño hispanolanguedociano, algo que se viene debatiendo desde los estudios realizados por Gaillard. En la p. 93 apunta que los artífices que intervinieron en las obras promovidas por la Infanta Urraca habían sido instruidos en Aquitania, Languedoc, Berry y acaso Borgoña.

36. Descrita como estructura polifuncional la mayoría de los investigadores son partidarios de su función cementerial y la consideran un camposanto dinástico como antecámara del Cielo. G. BOTO VARELA. "In Legionessy..." op. cit., pp. 93 y 108. Remitimos de nuevo a su estudio para consultar la bibliografía pertinente acerca de las diversas cuestiones tratadas en esta nota debido a su excesiva extensión. Para su función cementerial recientemente: J. MARTíNEZ DE AGUIRRE. "La memoria de la piedra: sepulturas en espacios monásticos hispanos (siglos XI y XII) En Monasterios Románicos y Producción Artística. Coord. J. A. GARCíA DE CORTAZAR. Aguilar de Campoo, 2003, p. 155 donde destaca su función funeraria. También M. CORTÉS ARRESE. "Pinceladas bizantinas. Pintura románica en el Panteón Real". En Real Colegiata de San Isidoro. Relicario de la Monarquía leonesa. León, 2007, pp. 146-167. El programa pictórico ha sido leído y razonado en clave escatológica por numerosos autores y en el caso de su escultura Moralejo reconoció una dimensión penitencial en los capiteles que flanquean la puerta del Cielo: S. MORALEJO ALVÁREZ. "La sculpture romane de la Cathedral de Jaca. Etat des qüestions". Les Cahiers de Saint-Michel de Cuxa, 10 (1979), pp. 79-106, así como en el programa pictórico: "Artistas, patronos y público en el arte del Camino de Santiago". ComposteIlanum, XXX (1985), pp. 411-412, y también en "Le origini del programma iconografico dei portali nel Romanico spagnolo". En Atti del Convegno: Wiligelmo e Lanfranco nell'Europa romanica". Módena, 1989, pp. 35-51. Incidiendo en la función penitencial: S. SILVA Y VERÁSTEGUI. "Espacios para la penitencia pública y sus programas iconográficos en el Románico Hispano". Clío \& Crimen, 7 (2010), pp. 111-136. Otros autores han considerado que el uso originario del espacio del Panteón sería su utilización como atrio o pórtico aúlico. Especialmente: J. WILLIAMS. "San Isidoro de León. Evidence for a new history". The Art Bulletin, 55-2 (1973), pp. 171-184 y recientemente "San Isidoro exposed: the vicissitudes of research in Romanesque Art". Journal of Medieval Iberian Studies 3-1 (2011), pp. 93-116. También: Th. MARTIN. "Mujeres, hermanas e hijas: el mecenazgo femenino en la familia de Alfonso VI". Anales de Historia del Arte. Volumen Extraordinario 2 (2011), pp. 147-179. Y de la misma autora. "Vie et mort dans le Panthéon de San Isidoro de León". Les Cahiers de Saint-Michel de Cuxa, 42 (2011), pp. 153-164. 


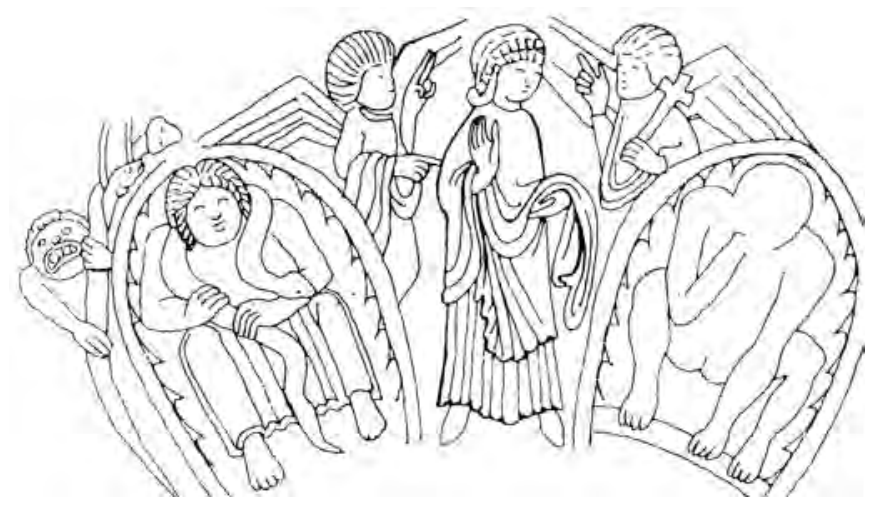

Figura 5. Dibujo del capitel de la nave de la Catedral de Jaca. Serafín Moralejo Álvarez (1977).

sodios evangélicos en la escultura románica hispana. Ambos temas se incluyen en las invocaciones de commendatio animae desde época paleocristiana ${ }^{37}$. Dichos temas tienen su reflejo en las manifestaciones de piedad y poder de Dios que se relatan en el Viejo Testamento, capiteles situados en el ángulo noroeste, justo enfrente, y que ya hemos señalado. En la escultura que se extiende hacia el lado occidental del Panteón es donde la alusión a lo pecaminoso se realiza a través de la representación del castigo a la lujuria ${ }^{38}$. Lo que realmente llama la atención en este caso es el hecho de que en un espacio tan privilegiado, una única imagen resulte suficiente para sintetizar el pecado, lo que lleva a considerar nuevamente no sólo su fortuna iconográfica, legitimada por su referente antiguo, sino la contundencia de su mensaje fuesen sus destinatarios la corte castellano-leonesa, los clérigos o los penitentes.

La última imagen que voy a resaltar difiere en su esquema iconográfico del resto de las femme-aux-serpents reseñadas hasta ahora. Fue de nuevo Moralejo uno de los primeros en Ilamar la atención sobre esta representación que figura

37. Se tienen datos de que esta oración que encomendaba el alma del difunto se rezaba en la iglesia de Antioquía. La traducción dice así: "Padre, libra su alma, como salvaste a Noé del diluvio, a Isaac de las manos de Abraham, a Jonás del monstruo marino, a Daniel del foso de los leones, a los tres jóvenes hebreos del horno, a Susana de los viejos" y continuaba dirigiéndose al Hijo: "Tú, también hijo de Dios, salva su alma, tú que abriste los ojos al ciego de nacimiento, curaste al paralítico, resucitaste a Lázaro...". dicha oración es por lo tanto una súplica constante a Dios para pedirle por la salvación del alma de los difuntos.

38. La distribución de los motivos se corresponde con los valores simbólicos de los puntos cardinales: los temas del Nuevo Testamento en el lado oriental, los del Viejo en el ángulo noroeste y los vinculados al pecado en el lado occidental. G. BOTO VARELA. "In Legionessy..." op. cit., p. 130, Nota 46. Una lectura reciente de los capiteles del Panteón ha propuesto la vinculación de sus motivos a un discurso apologético de la reforma gregoriana. J. MORÁN MORÁN. La recuperación de la "Ecclesiae Primitivae Forma". En La escultura del Panteón Real de San Isidoro de León. León, 2008. 
en un capitel interior de la Catedral de Jaca, en concreto en el del cuarto pilar del lado meridional ${ }^{39}$ (Fig. 5). El tema principal es la Anunciación, pero con un tratamiento particular, ya que aparece acompañada de dos ángeles uno de los cuales porta una cruz. Se ha relacionado con un capitel de la Puerta MiégeviIle de Saint-Sernin de Toulouse. Esta escena de la Anunciación está flanqueada por dos motivos con una clara significación negativa y en correspondencia antitética con María.

A la izquierda figura una mujer sentada que lleva una serpiente sobre los hombros y justo detrás suyo un ser demoníaco parece amenazarla con otras dos serpientes (Fig. 6). Moralejo la definió como "anunciación demoníaca" y vio en ella una imagen de Eva. En el ángulo contrario un simio agachado o en cuclillas parece llevarse la mano a la boca como si estuviera comiendo alguna cosa, simio que en su opinión se asemeja a los que aparecen en algunas representaciones del pasaje en el que Adán da nombre a los animales, como un preludio irónico de su pecado, y que suele figurar al lado de la imagen de Adán y Eva en el Paraíso. A su juicio la mujer y el simio ilustran una

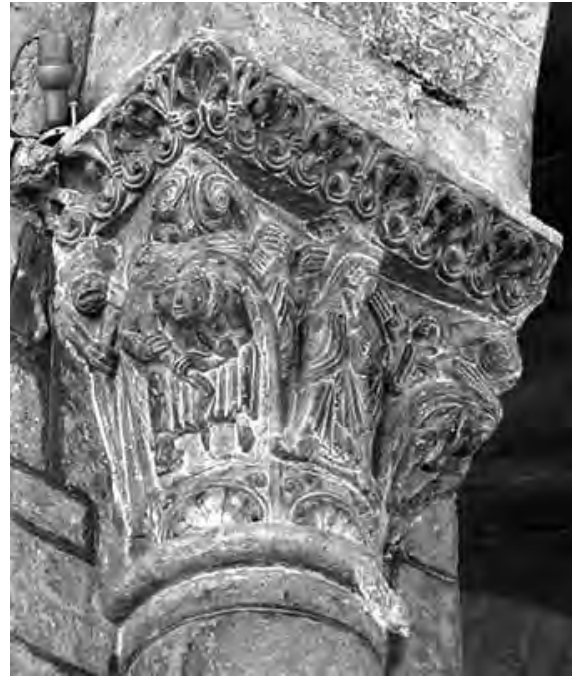

Figura 6. Capitel de la nave de la Catedral de Jaca. Fuente: http://romanicoaragones.com. parodia del pecado original y serían la imagen antitética de la Anunciación que al fin y al cabo preludia la Encarnación y por lo tanto la Redención.

Y continúa señalando que esta interpretación no contradice la evidente alusión a la lujuria de ambos personajes, mujer y simio, por la evidente connotación sexual que rodea al Pecado original. Ya tenemos una vez más la asociación Pecado Original, Eva y Lujuria, asociación a la que ya me he referido en ocasiones anteriores ${ }^{40}$ y en la que incido en aportaciones próximas a publicarse.

39. S. MORALEJO ÁLVAREZ. "Aportaciones a la interpretación del programa iconográfico de la catedral de Jaca". En Homenaje a José María Lacarra de Miguel en su jubilación del profesorado. Estudios Medievales I. Zaragoza, 1977, pp. 190-198. Retoma el tema en: "La sculpture romane de la cathédral de Jaca. État des questions". Les Cahiers de Saint-Michel de Cuxá, no 10 (1979), pp. 97-99.

40. E. MARTíNEZ DE LAGOS. "'La femme-aux-serpents'. Evolución iconográfica de la representación de la lujuria en el Occidente europeo medieval". Clío \& Crímen, ㄲo 7 (2010), pp. 137-158. 
Que la femme-aux-serpents es una de las imágenes más impactantes y elocuentes del imaginario medieval lo constata su extraordinaria difusión, difusión a la que sin duda contribuye el hecho de que sus primeras representaciones se encuentren esculpidas en centros artísticos primordiales en la expansión y divulgación del lenguaje románico. El éxito de la imagen es tal, que diversas representaciones de la Tierra-Madre en el siglo XII parecen haber recorrido el camino inverso, es decir de la lujuria a la Tierra-Madre, ya que muestran una clara contaminación de dicha iconografía. Una de las más elocuentes pertenece al cod. lat. 14399 conservado en la Bayerische Staatsbibliothek de München, códice que contiene el Hexaemeron de San Ambrosio y donde en el fol. 40 la miniatura

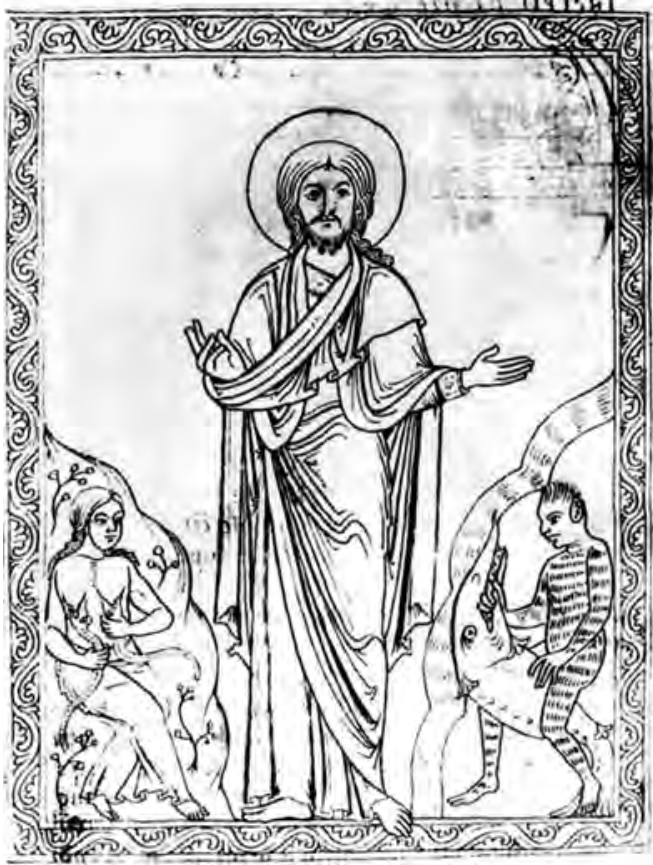

Figura 7. Fol. 40 del Cod. Lat. 14399. München, Bayerische Staatsbibliothek. Fuente: http://rdk.zikg.net/gsdl/ cgi-bin/library.exe. ilustra el tercer día de la Creación: "Que las aguas que están bajo los cielos se reúnan en un solo lugar, y aparezca lo seco. Y así fue. A lo seco lo llamo Dios tierra y al cúmulo de las aguas lo llamó mares..." (Gn. 1, 9-11). Dios aparece separando la tierra y el mar y en este caso la iconografía de la tierra muestra a una joven desnuda, sentada sobre una colina con flores y plantas y que sujeta con sus dos manos sendas serpientes que succionan sus pechos ${ }^{41}$. La inspiración en las imágenes carolingias e italianas de la Tierra-Madre es clara, pero también es evidente su relación con las numerosas representaciones de la lujuria que para este momento ya se han difundido por todo el Occidente europeo (Fig. 7).

41. La imagen de Océanos parece encerrar también cierto sentido negativo, ya que se representa a través de la imagen de un joven con todo el cuerpo cubierto de vello o de escamas y con el pelo llameante que cabalga sobre un gran pez. Se asemeja a ciertas figuras demoníacas o diábolicas difundidas en la iconografía románica. La miniatura de este códice del siglo XII en K. A. WIRTH. "Erde". Reallexicon zur deutschen Kunstgeschichte. T. V, p. 1059. Otros ejemplos similares figuran en un capitel de la Portada de Urcel o en otro de la Portada de St. María zur Höhe en Soest, donde las representaciones de la tierra parecen auténticas lujurias. 